\title{
KEMAMPUAN MENULIS KATA TULISAN ARAB MELAYU MAHASISWA PROGRAM STUDI PENDIDIKAN BAHASA INDONESIA FKIP UNIVERSITAS ISLAM RIAU
}

\author{
Muhammad Mukhlis ${ }^{1}$, Asnawi $^{2}$ \\ Universitas Islam Riau, Pekanbaru, Indonesia ${ }^{1,2}$ \\ m.mukhlis@edu.uir.ac.id ${ }^{l}$,asnawi@edu.uir.ac.id ${ }^{2}$
}

\begin{abstract}
This study focuses on the ability to write words in Malay Arabic script. This research problem is formulated about the ability to write two syllables and lebid from two syllables in Malay Arabic script. The purpose of the study is to describe in detail the ability to write Malay Arabic words and apply proper word-writing principles in Malay Arabic script. This research is a field research with quantitative type. This research was conducted in Language Education and Literature Program Indonesia FKIP Islamic University of Riau. The method used to collect data is by the test technique. The data of this research is the result of word writing skill test and applying correct wording principle in Malay Arabic script obtained from randomly taken sample of research. Analyzing data is done with the mean technique. The result of this research concludes that the ability of writing Arabic Malay words of students of Indonesian Language and Literature Education Program, Faculty of Teacher Training and Education, Islamic University of Riau is categorized with percentage of $71.72 \%$. Furthermore, the ability to write Malay Arabic words of the students of Indonesian Language and Literature Education Studies Program, Faculty of Teacher Training and Education, Islamic University of Riau based on two syllables categorized with a percentage of $72.09 \%$ and based on the word syuku words more than two words low category ie $64.36 \%$.
\end{abstract}

Keywords: writing, words, Malay Arabic script

\begin{abstract}
ABSTRAK
Penelitian ini berfokus pada kemampuan menulis kata dalam tulisan Arab Melayu. Masalah penelitian ini dirumuskan tentang kemampuan menulis kata dua suku kata dan lebid dari dua suku kata dalam tulisan Arab Melayu. Tujuan penelaahan adalah untuk mendeskripsikan secara rinci tentang kemampuan kemampuan menulis kata tulisan arab Melayu dan menerapkan kaidah penulisan kata yang tepat dalam tulisan Arab Melayu. Penelitian ini merupakan penelitian lapangan dengan jenis kuantitatif. Penelitian ini dilakukan di Program Studi Pendidikan Bahasa dan Sastra Indonesia FKIP Universitas Islam Riau. Metode yang digunakan untuk mengumpulkan data adalah dengan teknik tes. Data penelitian ini adalah hasil tes kemampuan menulis kata dan menerapkan kaidah penulisan kata yang tepat dalam tulisan Arab Melayu diperoleh dari sampel penelitian yang diambil secara acak. Penganalisisan data dilakukan dengan teknik rerata. Hasil penelitian menyimpulkan bahwa kemampuan menulis kata tulisan Arab Melayu mahasiswa Program Studi Pendidikan Bahasa dan Sastra Indonesia, Fakultas Keguruan dan Ilmu Pendidikan, Universitas Islam Riau berkategori sedang dengan presentase $71.72 \%$. Selanjutnya, kemampuan menulis kata tulisan Arab Melayu mahasiswa Program Studi Pendidikan Bahasa dan Sastra Indonesia, Fakultas Keguruan dan Ilmu Pendidikan, Universitas Islam Riau berdasarkan dua suku kata berkategori sedang dengan presentase $72.09 \%$ dan berdasarkan kata bersuku kata lebih dari dua kata berkategori rendah yakni $64.36 \%$.
\end{abstract}

Kata kunci: menulis, kata, tulisan Arab Melayu

\section{PENDAHULUAN}

Menulis merupakan hal yang sangat penting bagi kita, terutama bagi seorang mahasiswa.
Dalam perjalanan kami menjadi seorang mahasiswa, keterampilan berbahasa yang satu ini selalu diperlukan selama kita menjadi 
seorang mahasiswa dan sampai menjadi seorang pendidik. Sebagai contoh dalam menulis makalah untuk tugas mata kuliah dan menulis skripsi, menulis sangat berperan penting sebagai bekal kami untuk menyampaikan pikiran dan gagasan mahasiswa pada saat kami kuliah maupun ketika kelak kami menjadi seorang pendidik. Menulis itu sangat penting karena setiap hari kita pasti akan melakukan yang namanya menulis.

Aktivitas menulis melibatkan unsur penulis sebagai penyampai pesan, pesan atau isi tulisan, saluran atau media tulisan, dan pembaca sebagai penerima pesan. Sebagai suatuketerampilan berbahasa, menulis merupakan kegiatan yang kompleks karena penulis dituntut untuk dapat menyusun dan mengorganisasikan isi tulisannya serta menuangkannya dalam formulasi ragam bahasa tulis dan konvensi penulisan lainnya (Suparno dan Yunus, 2004:26).

Penguasaan bahasa dan penguasaan menulis dalam penulisan merupakan faktor penting yang harus diketahui sejak awal. Aspek bahasa dalam menulis terkait dengan sikap, pembaca, dan tujuan. Sikap, pembaca, dan tujuan akan mempengaruhi bagaimana menulis kalimat, pilihan kata, dan gaya bahasa. Penguasaan bahasa dan penguasaan menulis yang baik akan mempermudah memilih yang akan digunakan sebagai media tulisannya.

Menulis dapat dikatakan sebagai kegiatan yang membentuk simbol-simbol. Tetapi menulis lebih dari sekedar memproduksi simbol grafis, seperti berbicara yang diartikan bukan hanya sebagai produksi suara. Simbol-simbol ini harus disusun, berdasarkan konvensi tertentu, untuk membentuk kata-kata dan kata-kata disusun untuk membentuk kalimat. Secara sederhana hakikat menulis, yaitu menuangkan ide atau pikiran secara tertulis. Menurut Kamus Besar Bahasa Indonesia., "menulis adalah menyusun suatu cerita buku dan sebagainya. (Alwi, dkk. 2003:506). Sejalan dengan pengertian di atas, Learner (dalam Abdurrahman, 1996:192) mengemukakan,bahwa " menulis atau mengarang adalah mengemukakan ide dalam bentuk visual." Lebih jauh, Sumarmo (1989:7) mengemukakan, bahwa "menulis adalah mengungkapkan bahasa dalam bentuk simbol gambar."

Menulis dapat didefinisikan sebagai suatu kegiatan berkomunikasi atau penyampaian pesan dengan menggunakan bahasa tulis sebagai medianya (Suparno dan Yunus: 2003: 3). Menurut Akhadiah (1998:3), menulis adalah suatu aktifitas bahasa yang menggunakan tulisan sebagai medianya. Menulis dapat diartikan sebagai kegiatan menuangkan ide atau gagasan dengan menggunakan bahasa tulis sebagai media penyampai (Tarigan, 1986: 15). Menulis, menurut Mc Crimmon (dalam Saddhono dan Slamet, 2014: 151), merupakan kegiatan menggali pikiran dan perasaan mengenai suatu objek, memilih hal-hal yang akan ditulis, menentukan cara menuliskannya sehingga pembaca dapat memahaminya dengan mudah dan jelas.

Slamet (2008:72) mengemukakan kemampuan menulis yaitu kemampuan berbahasa yang bersifat produktif; artinya, kemampuan menulis ini merupakan kemampuan yang menghasilkan; dalam hal ini menghasilkan tulisan.

Menurut Solehan, dkk (2008:94) kemampuan menulis bukanlah kemampuan yang diperoleh secara otomatis. Solehan menjelaskan bahwa kemampuan menulis seseorang bukan dibawa sejak lahir, melainkan diperoleh melalui tindak pembelajaran. Berhubungan dengan cara pemerolehan kemampuan menulis, seseorang yang telah mendapatkan pembelajaran menulis belum tentu memiliki kompetensi menulis dengan andal tanpa banyak latihan menulis.

Dengan menulis seseorang dapat mengungkapkan pikiran dan gagasan untuk mencapai maksud dan tujuannya. Tarigan (1982:21) mengatakan bahwa menulis ialah menurunkan atau melukiskan lambanglambang grafik yang menggambarkan suatu bahasa yang dipahami oleh seseorang, sehingga orang-orang lain dapat membaca lambang-lambang grafik tersebut, kalau mereka memahami bahasa dan gambaran tersebut. Senada dengan Tarigan, Nurudin (2007:4) menyebutkan bahwa menulis adalah segenap rangkaian kegiatan seseorang dalam 
rangka mengungkapkan gagasan dan menyampaikannya melalui bahasa tulis kepada orang lain agar mudah dipahami. Definisi menulis ini mengungkapkan bahwa menulis yang baik adalah menulis yang bisa dipahami oleh orang lain, sedangkan Wiyanto (2004:12) menyebutkan bahwa menulis mempunyai mempunyai dua arti. Pertama, menulis berarti mengubah bunyi yang dapat didengar menjadi tanda-tanda yang dapat dilihat. Bunyi-bunyi yang dirubah itu bunyi bahasa (bunyi yang berasal dari alat ucap manusia). Kedua, kata menulis mempunyai arti kegiatan mengungkapkan gagasan secara tertulis. Gagasan yang telah ditulis kemudian ditampung oleh pembaca dengan cara membaca.

Akhadiah (1988:2) mengatakan bahwa kemampuan menulis merupakan kemampuan yang kompleks, yang menuntut sejumlah pengetahuan dan keterampilan. Untuk menulis karangan yang sederhana, secara teknis seseorang dituntut memenuhi persyaratan dasar seperti menulis karangan yang rumit. Suparno (2007:13) mendefinisikan bahwa menulis sebagai suatu kegiatan penyampaian pesan (komunikasi) dengan menggunakan bahasa tulis sebagai alat atau medianya. Dalam komunikasi tulis paling tidak terdapat empat unsur yang terlibat: penulis sebagai penyampai pesan (penulis), pesan atau isi tulisan, saluran atau media berupa tulisan, dan pembaca sebagai penerima pesan.

Dari uraian di atas, dapat disimpulkan bahwa menulis merupakan salah satu keterampilan berbahasa yang digunakan untuk mengungkapkan pikiran atau gagasan dan untuk menyampaikan pesan (komunikasi) melalui bahasa tulis sebagai alat atau medianya, sehingga mudah untuk dipahami oleh pembaca. Kemampuan menulis merupakan kemampuan yang kompleks, yang menuntut sejumlah pengetahuan dan keterampilan. Dalam komunikasi tulis paling tidak terdapat empat unsur yang terlibat, yaitu: penulis sebagai penyampai pesan, pesan atau isi tulisan, saluran atau media berupa tulisan, dan pembaca sebagai penerima pesan.

Menurut Nurgiyantoro (2014:422), aktivitas menulis merupakan sebuah bentuk manifestasi kompetensi berbahasa paling akhir dikuasai pembelajar bahasa setelah kompetensi menyimak, berbicara dan membaca. Dibandingkan ketiga kompetensi bahasa tersebut, kompetensi menulis dapat dikatakan lebih sulit untuk dikuasai bahkan oleh penutur asli bahasa yang bersangkutan sekalipun. Hal ini disebabkan karena kompetensi menulis menghendaki penguasaaan berbagai unsur kebahasaan dan unsur di luar bahasa itu sendiri yang akan menjadi isi dari tulisan. Baik unsur bahasa maupun unsur isi pesan harus terjalin sedemikian rupa sehingga menghasilkan tulisan yang runtut, padu dan berisi. Kegiatan menulis menghendaki orang untuk menguasai lambang atau simbol-simbol visual dan aturan tata tulis, khususnya yang menyangkut masalah ejaan (Nurgiyantoro, 2014:423).

Pembelajaran Tulisan Arab Melayu pada dasarnya adalah proses mempelajari kaidah aksara Arab Melayu. Dalam mempelajari Tulisan Arab Melayu tentu tidak luput dari kesalahan. Corder (1990:62) menyatakan bahwa semua orang yang belajar bahasa pasti tidak luput dari kesalahan. Ingatlah bahwa kesalahan itu sumber inspirasi untuk menjadi benar. Studi mengenai kesalahan dan hubungannya dengan pengajaran Tulisan Arab Melayu perlu digalakkan sebab melalui kegiatan kajian kesalahan itu dapat diungkapkan berbagai hal berkaitan dengan kesalahan Tulisan Arab Melayu yang dilakukan oleh mahasiswa atau pembelajar. Apabila kesalahan-kesalahan itu telah diketahui, dapat dugunakan sebagai umpan balik dalam penyempurnaan pengajaran Tulisan Arab Melayu.

Hubungan antara pengajaran Tulisan Arab Melayu dengan kesalahan berbahasa itu sangat erat. Bahkan Tarigan (1990: 67) mengatakan bahwa hubungan keduanya ibarat air dengan ikan. Sebagaimana ikan hanya dapat hidup dan berada di dalam air, begitu juga kesalahan berbahasa sering terjadi dalam pembelajaran Tulisan Arab Melayu.

Para pakar linguistik dan para dosen Tulisan Arab Melayu Indonesia sependapat bahwa kesalahan berbahasa itu mengganggu pencapaian tujuan pengajaran Tulisan Arab Melayu. Oleh sebab itu, kesalahan Tulisan Arab Melayu yang sering dibuat mahasiswa harus dikurangi dan dihapuskan. Kesalahan 
penulisan Tulisan Arab Melayu merupakan suatu proses yang didasarkan pada analisis kesalahan mahasiswa atau seseorang yang sedang mempelajari sesuatu, misalnya, Tulisan Arab Melayu. Tulisan Arab Melayu itu bisa Tulisan Arab Melayu daerah, Tulisan Arab Melayu Indonesia, bisa juga Tulisan Arab Melayu asing.

Kemampuan menguasai Tulisan Arab Melayu secara baik dapat dilakukan seseorang dengan cara mempelajarinya, yaitu berlatih berulang-ulang dengan pembetulan di sanasini. Proses pembelajaran ini tentunya menggunakan strategi yang tepat agar dapat memperoleh hasil yang positif. Analisis kesalahan penulisan Tulisan Arab Melayu, ditujukan kepada Tulisan Arab Melayu yang sedang dipelajari atau ditargetkan sebab analisis kesalahan dapat membantu dan bahkan sangat berguna sebagai kelancaran program pengajaran yang sedang dilaksanakan. Maksudnya, dengan analisis kesalahan para dosen dapat mengatasi kesulitan yang dihadapi mahasiswa.

Kesalahan itu biasanya ditentukan berdasarkan kaidah atau aturan yang berlaku dalam Tulisan Arab Melayu yang sedang dipelajari. Jika kata atau kalimat yang digunakan mahasiswa atau pembelajar tidak sesuai dengan kaidah yang berlaku, maka pembelajar Tulisan Arab Melayu dikatakan membuat kesalahan. Dalam kaitannya dengan pengertian analisis kesalahan. Tarigan (1990:68) juga mengatakan bahwa analisis kesalahan adalah suatu proses kerja yang digunakan oleh para dosen dan peneliti. Kesalahan penulisan Tulisan Arab Melayu itu bisa terjadi disebabkan oleh kemampuan pemahaman mahasiswa atau pembelajar Tulisan Arab Melayu. Artinya, mahasiswa memang belum memahami sistem Tulisan Arab Melayu yang digunakan. Kesalahan biasanya terjadi secara sistematis. Kesalahan jenis ini dapat berlangsung lama bila tidak diperbaiki. Perbaikannya biasanya dilakukan oleh dosen. Misalnya, melalui pengajaran pelatihan, praktik, dan sebagainya. Kadangkala sering dikatakan bahwa kesalahan merupakan gambaran terhadap pemahaman mahasiswa akan sistem Tulisan Arab Melayu yang sedang dipelajari. Bila tahap pemahaman mahasiswa akan sistem Tulisan Arab Melayu yang dipelajari ternyata kurang, kesalahan akan sering terjadi. Kesalahan akan berkurang bila tahap pemahamannya semakin baik.

Pentingnya pengajaran Arab Melayu bagi generasi sekarang agar mampu membaca dan menulis Arab Melayu, merupakan suatu harapan dan kebanggaan bersama. Pengajaran tersebut bertujuan agar generasi sekarang mampu membaca dan menulis Arab Melayu serta memahami isi naskah karya sastra lama yang bertuliskan Arab Melayu. Arti penting pengajaran menganalisis kesalahan kata dalam wacana tulisan Arab Melayu dapat kita contohkan ketika nantinya mengadakan penelitian terhadap naskah lama yang bertuliskan Arab Melayu. Berarti kita telah berusaha menggali, menginventaris, dan mengembangkan suatu kebudayaan daerah untuk menopang kebudayaan nasional. Modal utama yang harus dimiliki adalah kemampuan membaca dan memahami naskah. Tanpa adanya kemampuan membaca dan memahami dari seorang peneliti, dapat dipastikan bahwa penelitian yang dilakukan akan mengalami hambatan bahkan cenderung mengalami kegagalan.

Provinsi Riau mempunyai sejarah yang sangat maju dan tinggi tentang peninggalan kebudayaan yang bertuliskan tulisan Arab Melayu. Agar generasi muda dapat mengenal dan membaca tulisan Arab Melayu, serta dapat membaca sejarah, nasihat, dan kisah lainnya yang bertuliskan tulisan Arab Melayu, maka Pemerintah Provinsi Riau memberlakukan mata pelajaran Arab Melayu. Pemberlakuannya ditetapkan dengan SK Dirjen Dikdasmen Nomor 173/Kep/87 pada tanggal 7 Oktober 1987 dan diperkuat dengan Keputusan Kepala Kantor Wilayah Departemen Pendidikan dan Kebudayaan Provinsi Riau Nomor 24/KPTS/Pp/1994 tentang pelajaran Arab Melayu merupakan pilihan wajib muatan lokal Provinsi Riau pada tingkat pendidikan.

Mahasiswa Program Studi Pendidikan Bahasa dan Sastra Indonesia FKIP Universitas Islam Riau adalah calon-calon guru mata pelajaran bahasa Indonesia di sekolah tempat mengajarnya nanti apabila telah dinyatakan lulus, namun tidak tertutup kemungkinan bisa 
menjadi guru mata pelajaran Arab Melayu. Sebab, saat mengikuti masa perkuliahan, Arab Melayu sebagai salah satu mata kuliah yang wajib dipelajari dengan beban 2 SKS. Berarti, mahasiswa tersebut sudah memiliki bekal untuk mengajarkan pelajaran Arab Melayu nantinya. Dari beberapa penelitian terdahulu yang telah penulis temukan dan telah dibaca, sepengetahuan penulis kemampuan mahasiswa dalam membaca pemahaman terutama pada wacana bertuliskan Arab Melayu masih jarang diteliti. Padahal dalam pembelajaran Arab Melayu, kemampuan menulis dan menganalisis kesalahan penulisan kata juga sangat diperlukan. Bertumpu dari berbagai pemaparan di atas, penulis termotivasi untuk mengadakan penelitian lanjutan terhadap Arab Melayu yaitu pada kemampuan menganalisis kesalahan penulisan kata dalam wacana tulisan Arab Melayu dan penerapan kaidah penulisan tulisan Arab Melayu pada mahasiswa.

\section{METODOLOGI PENELITIAN}

Penelitian ini dilaksanakan di Pekanbaru pada Program Studi Pendidikan Bahasa dan Sastra Indonesia FKIP Universitas Islam Riau. Penelitian ini dilaksanakan selama enam bulan terhitung mulai bulan Agustus sampai dengan Desember 2017. Jenis penelitian yang digunakan dalam penelitian ini adalah jenis penelitian kuantitatif, yaitu penelitian yang menghasilkan data angka berupa persentase hasil kemampuan menganalisis kata pada wacana tulisan Arab Melayu. Dengan demikian, penelitian ini diwujudkan dengan menafsirkan satu variabel data kemudian menghubungkannya dengan variabel data yang lain dan disajikan dalam bentuk angka atau presentase. (Arikunto, 1993:209)

Metode pengumpulan data dalam penelitian ini dengan menggunakan tes kemampuan menganalisis kesalahan penulisan kata pada wacana tulisan Arab Melayu. Data penelitianini merupa hasil tes kemampuan menganalisis kesalahan penulisan kata dalam wacana tulisan Arab Melayu yang diperoleh dari sampel penelitian. Sampel penelitian dijadikan sumber data dalam penelitian ini dengan populasi mahasiswa semester 3 Program Studi Pendidikan Bahasa dan Sastra Indonesia FKIP Universitas Islam Riau Tahun
Akademis 2017/2018. Kata populasi berasal dari istilah dalam bahasa Inggris yakni population yang bermakna jumlah penduduk. Terkait dengan hal tersebut, populasi adalah sekelompok orang, benda atau hal uang menjadi sumber pengambilan sampel; sekumpulan orang yang memenuhi syaratsyarat tertentu yang berkaitan dengan masalah penelitian (Razak, 2010:101). Berdasarkan uraian tersebut, yang menjadi populasi dalam penelitian ini adalah seluruh mahasiswa semester 3 Program Studi Pendidikan Bahasa dan Sastra Indonesia FKIP Universitas Islam Riau Tahun Akademis 2017/2018, dengan jumlah 186 orang mahasiswa. Pada penelitian ini, analisis data yang penulis gunakan adalah analisis dengan menggunakan rerata dan presentase.

\section{HASIL DAN PEMBAHASAN}

Berdasarkan deskripsi data peneltian yang telah dilakukan, pada bagian ini akan dibahas secra terperinci mengenai data-data yang ditemukan pada intrumen tes penelitian. Kemampuan menulis kata tulisan Arab Melayu mahasiswa Program Studi Pendidikan Bahasa dan Sastra Indonesia, Fakultas Keguruan dan Ilmu Pendidikan, Universitas Islam Riau berkategori sedang dengan presentase $71.72 \%$. Selanjutnya, kemampuan menulis kata tulisan Arab Melayu mahasiswa Program Studi Pendidikan Bahasa dan Sastra Indonesia, Fakultas Keguruan dan Ilmu Pendidikan, Universitas Islam Riau berdasarkan dua suku kata berkategori sedang dengan presentase $72.09 \%$ dan berdasarkan kata bersuku kata lebih dari dua kata berkategori rendah yakni $64.36 \%$. Secara rinci mengenai data tersebut, berikut akan dipaparkan secara rinci tentang kemampuan menulis kata Tulisan Arab Melayu berdasarkan suku katanya, kelas, dan jenis kelaman. Berikut akan dipaparkan secara terperinci.

Kemampuan menulis kata tulisan Arab Melayu mahasiswa Program Studi Pendidikan Bahasa dan Sastra Indonesia, Fakultas Keguruan dan Ilmu Pendidikan, Universitas Islam Riau berkategori sedang dengan presentase $71.72 \%$. Selanjutnya, kemampuan menulis kata tulisan Arab Melayu mahasiswa Program Studi Pendidikan Bahasa dan Sastra 
Indonesia, Fakultas Keguruan dan Ilmu Pendidikan, Universitas Islam Riau berdasarkan dua suku kata berkategori sedang dengan presentase $72.09 \%$ dan berdasarkan kata bersuku kata lebih dari dua kata berkategori rendah yakni $64.36 \%$. Berikut akan dipaparkan secara terperinci pada bagian di bawah ini.

\section{Kemampuan Menulis Kata Bersuku Kata Dua Suku Kata Tulisan Arab Melayu}

Kemampuan menulis kata tulisan Arab Melayu mahasiswa Program Studi Pendidikan Bahasa dan Sastra Indonesia, Fakultas Keguruan dan Ilmu Pendidikan, Universitas Islam Riau berkategori sedang dengan presentase $71.72 \%$. Selanjutnya, kemampuan menulis kata tulisan Arab Melayu mahasiswa Program Studi Pendidikan Bahasa dan Sastra Indonesia, Fakultas Keguruan dan Ilmu Pendidikan, Universitas Islam Riau berdasarkan dua suku kata berkategori sedang dengan presentase $72.09 \%$. Hal ini membuktikan bahwa kemampuan menulis kata bersuku kata dua suku kata berkategori sedang. Mahasiswa telah memahami bagaimana kaidah penulisan kata dalam tulisan Arab Melayu yang bersuku kata dua suku kata. Kaidah-kaida penulisan kata dalam tulisan Arab Melayu dengan kategori dua suku kata memnag bersifat sederhana.

\section{Kemampuan Menulis Kata Bersuku Kata Lebih dari Dua Suku kata Tulisan Arab Melayu}

Kemampuan menulis kata bersuku kata lebih dari dua suku kata tulisan Arab Melayu mahasiswa Program Studi Pendidikan Bahasa dan Sastra Indonesia, Fakultas Keguruan dan Ilmu Pendidikan, Universitas Islam Riau berkategori rendah dengan presentase $64.36 \%$. Selanjutnya, kemampuan menulis kata tulisan Arab Melayu mahasiswa Program Studi Pendidikan Bahasa dan Sastra Indonesia, Fakultas Keguruan dan Ilmu Pendidikan, Universitas Islam Riau berdasarkan dua suku kata lebih dari dua suku kata belum dikuasai dengan baik oleh mahasiswa Program Studi Pendidikan Bahasa dan Sastra Indonesia, Fakultas Keguruan dan Ilmu Pendidikan, Universitas Islam Riau. Hal ini membuktikan bahwa kemampuan menulis kata bersuku kata lebih dari dua suku kata berkategori rendah. Mahasiswa belum memahami bagaimana kaidah penulisan kata bersuku kata lebih dari dua suku kata dalam tulisan Arab Melayu yang bersuku kata dua suku kata. Kaidah-kaida penulisan kata dalam tulisan Arab Melayu dengan kategori lebid dari dua suku kata atau lebih memnag bersifat komplek. Mahasiswa dituntut memahami bagaimana merangkai afiks dalam kata dasar yang melekat pada kata tulisan Arab Melayu. Kekomplekan kaidah yang ada didasarkan pada banyaknya aturan dalam menuliskan kata-kata tertentu pada tulisan Arab Melayu. Selain itu, kesalahan pemberian saksi pada kata yang memiliki suku kata lebih dari dua suku kata bersifat kompleks. Mahasiswa dituntut memahami kaidah bagaimana memunculkan saksi pada setiap kosakata yang lebih dari dua suku kata.

\section{Rekapitulasi Kemampuan Menulis Kata Tulisan Arab Melayu}

Berdasarkan hasil teks kemampuan menulis kata tulisan Arab Melayu, mahasiswa Program Studi Pendidikan Bahasa dan Sastra Indonesia, Fakultas Keguruan dan Ilmu Pendidikan, Universitas Islam Riau, dapat dibut rekapitulasi kemampun menulis kata tulisan arab melayu baik bersuku kata dua suku kata ataupun bersuku kata lebih dari dua suku kata. Berikut dapat dilihat pada tabel berikut.

Tabel 1

Kemampuan Menulis Kata Tulisan Arab

Melayu

\begin{tabular}{|r|l|r|r|r|}
\hline No & Indikator & \multicolumn{1}{|l|}{$\begin{array}{l}\text { Skor } \\
\text { Total }\end{array}$} & \multicolumn{1}{l|}{ Rerata } & Kategori \\
\hline 1 & Dua Suku Kata & 3480 & 79.09 & Sedang \\
\hline 2 & $\begin{array}{l}\text { Lebih Dua Suku } \\
\text { Kata }\end{array}$ & 2832 & 64.36 & Rendah \\
\hline \multicolumn{2}{|l|}{ Jumlah } & 6312 & 143.45 & \\
\hline \multicolumn{2}{|l|}{ Presentase } & & 71.72 & Sedang \\
\hline
\end{tabular}

Berdasarkan tebel di atas dapat diketahui bahwa kemampuan menulis kata tulisan Arab Melayu mahasiswa Program Studi Pendidikan Bahasa dan Sastra Indonesia, Fakultas Keguruan dan Ilmu Pendidikan, Universitas Islam Riau berkategori sedang dengan presentase $71.72 \%$. Selanjutnya, kemampuan menulis kata tulisan Arab Melayu 
mahasiswa Program Studi Pendidikan Bahasa dan Sastra Indonesia, Fakultas Keguruan dan Ilmu Pendidikan, Universitas Islam Riau berdasarkan dua suku kata berkategori sedang dengan presentase $72.09 \%$ dan berdasarkan kata bersuku kata lebih dari dua kata berkategori rendah yakni $64.36 \%$. Selanjutnya, berikut ini akan dipaparkan secara terperinci pada grafik di bawah ini.

Grafik 1

Kemampuan Menulis Kata Tulisan Arab Melayu

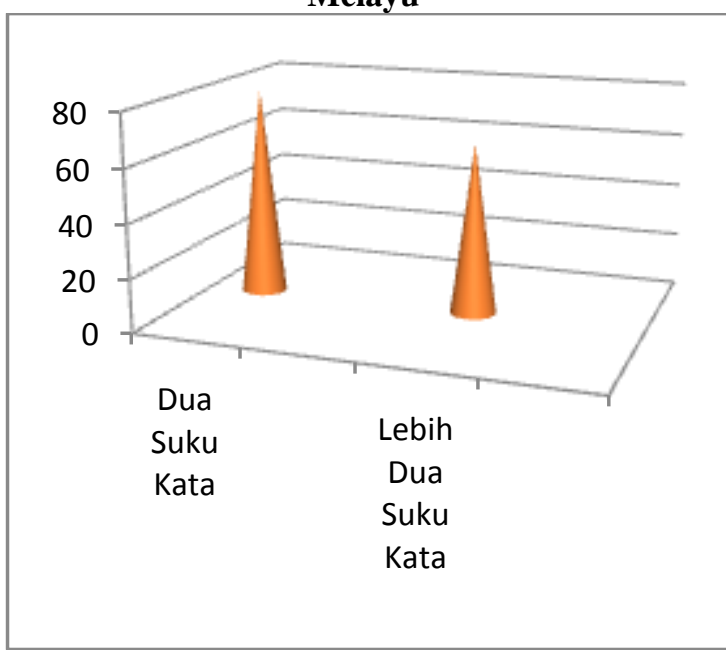

\section{SIMPULAN}

Berdasarkan hasil penelitian yang telah dinyatakan pada bagian sebelumnya, dapat disimpulkan bahwa Kemampuan menulis kata tulisan Arab Melayu mahasiswa Program Studi Pendidikan Bahasa dan Sastra Indonesia, Fakultas Keguruan dan Ilmu Pendidikan, Universitas Islam Riau berkategori sedang dengan presentase $71.72 \%$. Selanjutnya, kemampuan menulis kata tulisan Arab Melayu mahasiswa Program Studi Pendidikan Bahasa dan Sastra Indonesia, Fakultas Keguruan dan Ilmu Pendidikan, Universitas Islam Riau berdasarkan dua suku kata berkategori sedang dengan presentase $72.09 \%$ dan berdasarkan kata bersuku kata lebih dari dua kata berkategori rendah yakni $64.36 \%$.

\section{REFERENSI}

Arikunto, Suharsimi. 1993. Prosedur Penelitian. Jakarta: Rineka Putra.

Surana, FX. dkk. 1982. Menulis dan Membaca Huruf Arab Indonesia. Solo: Dikdasmen.
Tampubolon, DP. 1987. Kemampuan Membaca Teknis (Membaca Efektif dan Efisien). Bandung: Angkasa.

Tarigan, H.G. 1979. Membaca Sebagai Studi Keterampilan Berbahasa. Bandung: Angkasa.

Parera, Jos Daniel. 1997. Linguistic Edukasional. Jakarta: Erlangga.

S. Corder, Pit. 1982. Eror Analysis and Interlanguage. Oxford University Press.

Sujinah. 2004. Analisis Kesalahan Berbahasa Dalam Pengajaran Bahasa Indonesia. Surabaya:

Faizah, Hasnah. 2009. Kaidah Menulis Arab Melayu. Pekanbaru: Cendikia Insani.

Om, Fadillah. 2002. Pedoman Khusus Pengajaran Tulisan Arab Melayu untuk Kelas I, II, III SLTP. Pekanbaru: Usaha Putra Riau.

Om, Fadillah. 2005. Lambang Tulisan Arab Melayu Untuk Kelas III SLTP. Pekanbaru: Usaha Putra Riau.

Om, Fadillah. 2010. Lambang Tulisan Arab Melayu Untuk Kelas IV SD. Pekanbaru: Usaha Putra Riau.

Razak, Abdul. 2003. Bahasa Indonesia Versi Perguruan Tinggi. Pekanbaru: Autografika.

Razak, Abdul.. 2005. Statistik Pengolahan Data Sosial Sistem Manual. Pekanbaru: Autografika.

Razak, Abdul.. 2007. Membaca Pemahaman Teori dan Aplikasi Pengajaran. Pekanbaru: Autografika. 